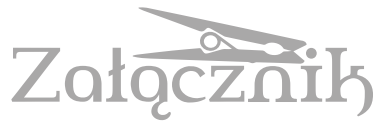

DOI 10.21697/zk.2020.7.20

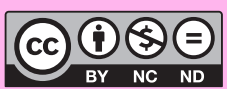

Załącznik Kulturoznawczy 7/2020

\title{
OPĘTANI W TEATRZE. ZABIEGI ADAPTACYJNE NA POWIEŚCI WITOLDA GOMBROWICZA W INSCENIZACJI KRZYSZTOFA GARBACZEWSKIEGO
}

KaTARZYNA Gotos-DąBROWSKA

Wydział Nauk Humanistycznych UKSW

Department of Humanities,

Cardinal Stefan Wyszyński University in Warsaw

katarzyna.golos.uksw@gmail.com

ORCID: 0000-0003-0908-7352

\section{SPÓR RECEPCYJNY WOKÓŁ OPETANYCH}

Opętani to powieść szczególna w dorobku autora Ferdydurke: drukowana przed wojną (1939), w odcinkach, na łamach „Kuriera Codziennego”, „Expresu Porannego” oraz „Kuriera Czerwonego” i podpisywana pseudonimem „Z. Niewieski”, tworzona z fascynacji gatunkami powieści popularnej i - a może przede wszystkim - dla zysku1. Na fabułę utworu składają się dwa główne ciągi zdarzeń - pierwszy, oparty na schemacie powieści kryminalnej z elementami spirytyzmu, oraz drugi, stylizowany na wzorcach znanych z gotyckiej powieści grozy. Pierwszy z nich dotyczy toksycznej relacji miłosnej między Mają Ochołowską (tenisistką, ziemianką z Połyki) a jej trenerem, Marianem Leszczukiem², wywodzącym się z klasy robotniczej. Dziedziną, na polu której dochodzi do spotkania się na równych prawach

1 J. Jarzębski, Opętani - zapomniana powieść Gombrowicza, [w:] idem, Powieść jako autokreacja, Kraków 1984, s. 68-69.

$2 \mathrm{~W}$ pierwszym rozdziale powieści bohater nazywany był Marianem Walczakiem. Po opublikowaniu premierowego rozdziału przyszła skarga do redakcji od rzekomo autentycznego trenera Walczaka, który nie życzył sobie, by zapożyczano jego dane. W rzeczywistości był to żart kolegów Gombrowicza; zob. ibidem, s. 70. 
pary głównych, a tak różnych klasowo bohaterów, jest sport - przestrzeń nowoczesna, a jednocześnie „demokratyczna”. Jak pisze Wojciech Śmieja:

Kariera sportowa Leszczuka przebiega według modelowego wzorca, tzn. młody, zdolny, ale biedny zostaje pomagierem przy korcie, tam dostrzega się jego talent, zostaje trenerem, ale po chłopięcemu marzy o międzynarodowej karierze tenisisty. Ten schematyczny model w przestrzeni cielesnej i społecznej doprowadza do katastrofy dotychczasowe hierarchie. [...]. Ciało Leszczuka jest tym bardziej niepokojące, że obnaża ordynarność ciała panny z dobrego domu - Mai. Dzięki sportowi wyzwoliło się, przynajmniej częściowo, z proletariackiego losu, ale ten sam sport eksponuje ciało dziewczyny, które w konfrontacji z cielesnością Leszczuka - w opinii połyczan - się wulgaryzuje. Wszyscy bohaterowie, także Leszczuk i Maja, dostrzegają tę niepokojącą analogię ciał przekraczających klasowe, majątkowe, społeczne, edukacyjne i kulturowe bariery ${ }^{3}$.

Kołem zamachowym drugiego ciągu fabularnego powieści jest wątek gotycki, związany z tajemnicą zamku w Mysłoczy znajdującej się nieopodal dóbr Ochołowskich, z którym wiąże się tajemnica zaginięcia lokajczyka, a jednocześnie nieślubnego syna księcia Holszańskiego - Frania. Po zniknięciu chłopca zaczyna straszyć: w starej kuchni zamkowej bez wyraźnego powodu faluje stary ręcznik, co sprawia, że wokół zamczyska rodzą się legendy.

Przez większość badaczy Opętani uważani są za utwór nieudany. Jak podkreśla Zdravko Mailć, sam Gombrowicz w liście prywatnym przyznaje, że powieść ta „nie ma najmniejszego znaczenia” i że napisał ją „trochę dla pieniędzy, trochę dla zabawy”. Jerzy Jarzębski określił ją jako „niezbyt poważną zabawkę pisarza”. Mimo że powieść uznał za marną, doszukiwał się jej wartości, głównie w stałych gombrowiczowskich motywach, m.in.: sobowtóra, opozycji starość-młodość, fetyszyzacji niedojrzałości, pociągu do tego, co „niskie”4.

Maria Janion w odpowiedzi na zarzuty Jarzębskiego dowodzi, iż opinia gombrowiczologa na temat powieści była wynikiem fałszywej kwalifikacji

3 W. Śmieja, Od ideologii ciała do cielesności zideologizowanej. Sport i literatura w latach 1918-1939, „Teksty Drugie” 2011, nr 4, s. 28-48.

${ }_{4}$ Zob. J. Jarzębski, op. cit., s. 68-69. 
gatunkowej (komercyjny, trywialny romans brukowy), jak i niezrozumienia miejsca utworu w twórczości pisarza. Badaczka zaznacza, że ostatni napisany w Polsce utwór Gombrowicza jest realizacją przekonań pisarza dotyczących braku podziału pomiędzy poważną i niepoważną, dobrą i złą literaturą, z czego ta druga, zdaniem autora, odsłania ważne rejony życia odbiorcy, do którego ma trafić. Badaczka w Gorączce romantycznej pisze o Opętanych jako o części bardzo rozbudowanego i konsekwentnego planu literackiego, twierdząc, że „w żadnym wypadku nie można traktować ich jako gorszego i wstydliwego marginesu jego twórczości”. Janion określa ostatni polski utwór Gombrowicza jako czystą powieść gotycką z elementami romansu i kryminału ${ }^{6}$. Dostrzega w utworze brakujące ogniwo literatury polskiej - powieść gotycką właśnie; jej zdaniem to jedyna „normalna” powieść Gombrowicza, w której „zło zostało potraktowane z metafizyczną powagą i została mu wydana walka"7.

Z tezą o metafizyczności powieści dyskutuje z kolei Dorota KorwinPiotrowska, zaznaczając, iż zostaje tu ona zniwelowana m.in. przez wprowadzanie motywów groteskowych oraz elementy komiczne, podważające atmosferę grozy, poniekąd ośmieszające konwencje gatunkowe, z których czerpie autor. Badaczka zwraca uwagę, że gatunek powieści gotyckiej jest w Opętanych parodiowany, co nie oznacza jednak, iż utwór przestaje być powieścią popularną. Z zupełnie innych względów niż Maria Janion doceniła go Ewa Graczyk w książce Przed wybuchem wstrząsnąć (publikacji traktującej o przedwojennej twórczości autora Ferdydurke). Autorka monografii określiła Opętanych jako utwór wręcz nie do przecenienia z uwagi na poruszaną w nim problematykę. Zwróciła uwagę na ogrom istotnych kulturowo tematów tej „nieudanej” powieści, m.in. hierarchizm, feudalizm, demokrację.

5 M. Janion, Forma gotycka Gombrowicza, [w:] eadem, Goraczka romantyczna, Warszawa 1975, s. 205.

6 Ibidem, s. 206.

7 Ibidem, s. 203.

8 E. Graczyk, Widmo Opętanych, [w:] eidem, Przed wybuchem wstrząsnać, Gdańsk 2004. 


\section{OPETANI NA DESKACH TEATRU}

Opętani nieczęsto gościli na deskach teatralnych. Czterokrotnie w latach 80. wystawiał swoją adaptację Tadeusz Minc w Teatrze Polskim we Wrocławiu (1980), Teatrze Narodowym w Warszawie (1982), Teatrze Współczesnym w Szczecinie (1987) i Teatrze Wybrzeże w Gdańsku (1987). Reżyser osadził Opętanych w problemach poruszanych w twórczości Gombrowicza; dostrzegł w nich klasyczne opozycje: młodość - dojrzałość, wyższość niższość, ideę „kościoła międzyludzkiego”, fascynację dwoistością świata i natury ludzkiej, a także - złem. Kolejnym wystawieniem powieści był spektakl z 2000 roku w reżyserii Andrzeja Pawłowskiego, który - jak się wydaje - miał być zaproszeniem do zabawy w stylu retro (powieść stała się dla adaptatora po prostu źródłem atrakcyjnych motywów, postaci i rozwiązań fabularnych).

Następną inscenizacją „złej powieści” Gombrowicza był spektakl w reżyserii Krzysztofa Garbaczewskiego, którego premiera miała miejsce 21 listopada 2008 roku w Teatrze Dramatycznym im. Jerzego Szaniawskiego w Wałbrzychu. Przedstawienie stanowiło jedną z pierwszych realizacji reżysera, dopiero kształtującego swoją wizję teatru. W tym czasie Garbaczewski zakwalifikowany został przez Marcina Kościelniaka do reprezentantów „pokolenia wieszaka” - to etykieta określająca kolejne pokolenie reżyserów,

9 Pierwszym pokoleniem polskich reżyserów określanych wspólnym terminem byli „młodzi zdolni”, nazwani tak przez Jerzego Koeninga: Jerzy Grzegorzewski, Roman Kordziński, Helmut Kajzar, Piotr Piaskowski, Maciej Prus, Izabella Cywińska, Bogdan Hussakowski. Reżyserzy ci nie tworzyli formalnej grupy. Elementem wspólnym dla ich twórczości było zainteresowanie estetyką, w przeciwieństwie do pokolenia starszych twórców - Erwina Axera, Adama Hanuszkiewicza, Konrada Swinarskiego - nie traktowali teatru jako oręża w walce $\mathrm{z}$ władzą PRL-u. Kolejnym umownie etykietowanym pokoleniem byli „młodsi zdolniejsi” - tak Piotr Gruszczyński m.in. w Ojcobójcach określił twórców teatru intensywnie działających po 1989 roku: Krystiana Lupę (prekursora umownej grupy), Annę Augustynowicz, Zbigniewa Brzozę, Piotra Cieplaka, Grzegorza Jarzynę i Krzysztofa Warlikowskiego. Nazewnictwa kolejnego pokolenia reżyserów teatralnych debiutujących w latach dwutysięcznych jest wiele. Poza wspomnianym „pokoleniem wieszaka” funkcjonują również takie określenie jak: „jeszcze młodsi, jeszcze zdolniejsi” (m.in. Paweł Miśkiewicz, Agnieszka Glińska, Piotr Kruszczyński, Jan Klata, Maja Klaczewska), „pokolenie porno” (określenie 
urodzonych w latach 80 . XX wieku, których twórczość nawiązywała do poetyki reklamy i estetyki gatunków popkulturowych. Określenie nadane grupie twórców teatralnych ukute zostało z uwagi na znaczący motyw (wieszak), często wykorzystywany w spektaklach twórców natenczas najmłodszego pokolenia (Natalii Korczakowskiej, Szymona Kaczmarka, Radosława Rychcika i właśnie Krzysztofa Garbaczewskiego) ${ }^{10}$ :

Zasadą jest, że wiszące na wieszaku kostiumy aktorzy zmieniają w trakcie przedstawienia; w ten sposób to, co zazwyczaj odbywa się w tajemnicy, za kulisami - tutaj dzieje się na oczach widzów. Nie chodzi tylko o podważenie iluzji. Rozchwiany status rzeczywistości uruchamia pytania o solidność teatralnych ról, ale także ról społecznych i kulturowych bohaterów przedstawień. Zawsze tylko na jakiś czas i określoną okazję formułowana tożsamość będzie punktem wyznaczającym teatralną optykę, regulującym możliwości scenicznej ekspresji ${ }^{11}$.

Choć sama etykieta przypisana do grupy reżyserów wypreparowanej spośród młodych twórców wydaje się ogromnym uproszczeniem, co więcej - nie zawsze przydatnym do porządkowania aktualnej twórczości członków tej generacji, to w przypadku refleksji nad wczesnymi spektaklami Garbaczewskiego przywołanie jej wydaje się nieodzowne.

Skrótowo rzecz ujmując, chwyt "nicowania” teatru, wprowadzania na scenę tego, co zazwyczaj ukrywane, gra z konwencjami oraz stosowanie licznych zabiegów anty- i deziluzyjnych w przypadku wyżej wskazanej inscenizacji Opętanych realizuje się na kilku polach. Służą temu w szczególności:

młodych dramaturgów autorstwa Romana Pawłowskiego, a jednocześnie tytuł jednego z dzieł twórców owego pokolenia - Pawła Jurka), „pokolenie niezadowolonych" (określenie młodych twórców najnowszego teatru zaangażowanego) czy „pokolenie baz@rtu” (określenie autorstwa Anny Krajewskiej dotyczące twórców pojmujących teatr jako performans).

${ }^{10}$ Oczywiście nie tylko; wieszak rodem $\mathrm{z}$ teatralnej garderoby pojawił się również w spektaklach Krystiana Lupy: Factory 2 (2008) oraz Persona. Marilyn (2009).

${ }_{11}$ M. Kościelniak, Pokolenie wieszaka, „Tygodnik Powszechny”, 17.02.2009, https://www.tygodnikpowszechny.pl/pokolenie-wieszaka-136116 [dostęp 5.09.2020]. 
a. tworzenie nielinearnych konstrukcji tekstowych na bazie inscenizowanego utworu przy jednoczesnej zmianie konwencji w jego scenicznej wersji;

b. prezentacja na scenie sytuacji związanych ze zmianami scenografii i strojów aktorów jako element gry z odbiorcą oraz środek służący artykulacji problemów związanych z tożsamością, m.in. klasową i płciową (przy czym przekształcenia obrazów scenicznych wiążą się również ze zmianami konwencji teatralnych - reżyser „przebiera” swój spektakl, przeplata sceny osadzone w różnych konwencjach, korzysta z rozmaitych klisz kultury popularnej);

c. nadawanie przestrzeni scenicznej wymiaru autoreferencyjnego.

\section{NIELINEARNA STRUKTURA FABULARNA}

Krzysztof Garbaczewski, którego twórczość wpisuje się w praktyki teatru postdramatycznego, kształtując scenariusze do spektakli, często zaburza hierarchię środków teatralnych oraz stosuje zabieg parataksy ${ }^{12}$, sprawiając, że odczytanie głównego tematu przedstawienia przez odbiorcę dokonuje się w procesie łączenia znaczeń poszczególnych epizodów w relacji z zastosowanymi środkami teatralnymi. Reżyser tworzy wariacje na temat tekstów, które inscenizuje, a ważnym punktem jego scenicznych interpretacji jest współczesna recepcja owych dzieł. Jak pisze dramaturg Żelisław Żelisławski: „Garbaczewski wynajduje w adaptowanych tekstach pęknięcia, które następnie uwypukla, często zaburzając strukturę inscenizowanego tekstu"13.

12 Zabieg parataksy w odniesieniu do teatru postdramatycznego wiąże się z tworzeniem struktur, które w przeciwieństwie do tradycyjnych rozwiązań podważają relację nadrzędności i podrzędności środków teatralnych (na szczycie hierarchii znaków stała do tej pory m.in. gestyka i sposób mówienia aktora, a jakości wizualne i architektoniczne były zepchnięte na drugi plan) oraz nie dążą do zharmonizowania świata przedstawionego. Niehierarchiczne użycie znaków prowadzi do synestezyjnej percepcji widza; zob.: H.-T. Lehmann, Parataksa / Brak hierarchii, [w:] idem, Teatr postdramatyczny, tłum. D. Sajewska, M. Sugiera, Kraków 2009.

13 Ż. Żelisławski, Uruchom ponownie. Strategie estetyczne i przeciwreżyserskie Krzysztofa Garbaczewskiego, [w:] Odsłony współczesnej scenografii. Problemy Sylwetki - Rozmowy, red. K. Fazan, A. Marszałek, J. Rożek-Sieraczyński, Kraków 2016, s. 141. 
Tak też jest w przypadku Opętanych. Wraz Katarzyną Warnke, odpowiedzialną za dramatyzację utworu, reżyser szatkuje historię napisaną przez Gombrowicza, by zrealizować dwa założenia: wyeksponować pastiszowy charakter utworu wyjściowego oraz wydobyć na plan pierwszy jego problematykę (niekiedy w powieści przyćmiewaną przez sensacyjny charakter utworu i dynamikę fabuły), dotyczącą m.in. poszukiwania tożsamości, poczucia wstydu i społecznego niedopasowania.

Pierwszym widocznym zabiegiem dokonanym na prozie powieściowej w celu jej dostosowania do medium teatru jest w prowa d zenie różn e go typu narratorów scenicznych. Spektakl zaczyna się od końca wątku warszawskiego powieści, czyli od śledztwa w sprawie śmierci Maliniaka bogatego przedsiębiorcy, u którego zatrudnia się Maja po ucieczce z rodzinnej Połyki. W tej scenie rolę narratora (co istotne - trzecioosobowego) pełni sam martwy Maliniak (Adam Wolańczyk). Bohater, patrząc w obiektyw niewielkiej kamery, opowiada o wydarzeniach przeszłych, a następnie komentuje akcję sceniczną, co widz ogląda w powiększeniu na ekranie telewizora umieszczonego na scenie. Hiperboliczny, powielony obraz Maliniaka, zestawiony z przerysowaną grą aktorską Marty Zięby grającej hrabinę Di Mildi (kuzynkę, a zarazem zabójczynię Maliniaka), sprawia, że zostajemy wprowadzeni przez twórców w świadomie kiczowaty świat sceniczny, celowo eksponujący słabość gatunku popularnego, jakim jest kryminał. Odbiorca już od pierwszej sceny wie, kto zabił „gadającego trupa”, a z kolejnych dowiaduje się, jak finalnie (w świecie powieściowym) wyglądać będzie relacja ziemianki i trenera. Widz jednak nie zostaje zachęcony do rekonstruowania kryminalnej fabuły, skupia się nie na niej, a na sposobie jej przedstawienia. Nielinearna struktura powoduje, że uwaga zostaje skoncentrowana raczej na rozszyfrowaniu kolażu konwencji użytych przez twórcę ${ }^{14}$.

Trzecioosobowa narracja sceniczna służy również wyeksponowaniu teatralności zachowań społecznych opisanych w powieści. Prowadzona jest m.in. przez przyjaciół Mai: młodą parę (Andrzej Kłak i Małgorzata Białek)

14 Krzysztof Garbaczewski jawnie deklaruje, iż w swoim teatrze nie szuka sensu, ale doświadczenia, a jego twórczości (podobnie jak współczesnemu teatrowi tańca) bliżej jest do performansu niż do opowiadania historii. Zob. Energia. Rozmowa Romana Pawłowskiego z Krzysztofem Garbaczewskim, „Notatnik Teatralny” 2016, nr 82, s. 61. 
oraz - przebraną za śpiewaczkę operową - kucharkę księcia, Ziółkowską (Ewelina Żak), która komentuje rozgrywkę Mai (Paulina Chapko) i Leszczuka (Rafał Kosowski), stylizując swą wypowiedź na profesjonalny komentarz sportowy.

Ta zabawa formami i konwencjami, które dają się wpisać w inscenizację powieści, oraz dekonstrukcja sensacyjnej fabuły służą twórcom do opowiedzenia ważkich dla nich tematów dostrzeżonych w Gombrowiczowskiej „próbie powieści popularnej”. Przedstawione wydarzenia poprzeplatane są retrospekcjami i monologami bohaterów, w dużej mierze będącymi ich autoprezentacją, która w prowadza do spektaklu punkty widzenia z perspektywy postaci. Trzecia scena to monolog matki Mai, czytającej list do córki, w którym zwierza się z bólu, jaki sprawia jej niemożność porozumienia się z dzieckiem, i wyraża obawy co do tego, czy na pewno miłość, a nie wyrachowana interesowność leżą u podstaw narzeczeństwa Mai z Cholawickim (sekretarzem księcia). Z kolei w piątej scenie pierwszego aktu Leszczuk opowiada historię swojego trudnego dzieciństwa pod opieką agresywnego ojca oraz młodości w klubie tenisowym. Drugi akt rozpoczyna się od mrocznej sceny rekonstruującej życie syna Holszańskiego na zamku i prezentuje jego homoerotyczną, kazirodczą relację z księciem. Przewodnikiem po wydarzeniach z przeszłości jest Grzegorz - stary sługa Holszańskiego, opowiadający historię „Z offu”.

Reżyser z pewnością nie tylko po to restrukturyzuje fabułę, by „zabawić się" gatunkami literackimi i formami teatralnymi. Kolejnym zabiegiem na opowieści Gombrowicza jest dialogizacja narracji trzecioosobowej, zastosowana m.in. w celu uzyskania efektu komicznego. Przykładem może być scena, w której Leszczuk pokazuje Mai sposób na ścięcie piłki rakietą tenisową, niemożliwe do odbicia przez przeciwnika:

Chciała go zapytać, jak wpadł na to, ale w formie bezosobowej to pytanie było trudne do postawienia.

- A co? Przecie jak bym wygrał... to i nam byłoby łatwiej. Miałbym przynajmniej jakieś stanowisko.

- Aha - to on podchodził do tego tak... matrymonialnie? - Chciała się odsunąć z odrazą, ale - przecież to był jej uśmiech, jej sposób mówienia, ona zupełnie tak samo mogłaby to powiedzieć. I zresztą czyż ona była lepsza? Ot, głupi ordynarny chłopak i zdeklasowana panna. 
Zostaje to w spektaklu przetworzone następująco:

MAJA: Chcę cię zapytać, jak wpadłeś na to, ale w formie bezosobowej to pytanie jest trudne do postawienia.

LESZCZUK: A co? Przecie jak bym wygrał... to i nam byłoby łatwiej. Miałbym przynajmniej jakieś stanowisko.

MAJA: Aha, to ty podchodzisz do tego matrymonialnie? Chcę odsunąć się z odrazą! Zresztą, czy ja byłam lepsza? Ot, głupi ordynarny chłopak i zdeklasowana panna.

Garbaczewski, wpisując się w praktyki teatru postdramatycznego, nie tworzy z powieści autora Ferdydurke formy dramatycznej, ale uwzględnia narrację powieściową, by zaznaczyć swoistość materii, która zostaje zainscenizowana, a jednocześnie opowiedzieć o poruszanych w niej uniwersalnych problemach. Spektakl kończy scena bezskutecznego wywoływania złego ducha $z$ „opętanego” Leszczuka. Przedstawienie zamyka się wielokrotnym powtórzeniem przez Hincza-medium pytania „Kim jesteś?”. Zawieszony w połowie powieściowej sekwencji finał spektaklu nie tylko zmienia znaczenie samego opętania, ale zmienia również sens historii ofiar społecznej nierówności.

\section{TEATRALNE ŚRODKI GRY Z KONWENCJAMI}

Garbaczewski w swojej inscenizacji podąża za ideą zabawy konwencjami realizowaną w literaturze przez Gombrowicza ${ }^{15}$, a jednocześnie sam łączy i nicuje różne teatralne formy, ale nie tylko - wprowadza elementy przypominające pastisz opery, kabaretu, korzysta z „operacji świetlnych” znamiennych dla klasycznego horroru, używa też elementów choreograficznych charakterystycznych dla pokazów mody. W spektaklu najczytelniejszą kliszą zapożyczoną z kultury popularnej (i nie tylko) jest niewątpliwie „praca świateł".

15 Idea ta jest ściśle spleciona z Gombrowiczowską koncepcją artyzmu (i Gombrowiczowską refleksją antropologiczną), której istotny rys określa opozycja ciężaru i lekkości, zob. B. Pawłowska-Jądrzyk, Młodość jako „sekretna alchemia odciążająca". W kręgu idei Witolda Gombrowicza, [w:] Ciężar i lekkość w kulturze. Estetyka, poetyka, style myślenia, red. B. Pawłowska-Jądrzyk, Warszawa 2016, s. 241-248. 
Światło na wybiegu (będącym „przedłużeniem” sceny) nie tylko wzbudza niepokój, ale również wprowadza subtelne nawiązania do gotycyzmu. Przykładem może być początek sceny z pierwszego aktu, w której przyjazd gości do dworu relacjonowany jest przez Pannę Młodą. Narratorka, snująca opowieść o starym zamku w Mysłoczy, stoi na początku wybiegu, ale pozostaje wyciemniona. Jedyne światło, które pozwala dostrzec kontur postaci, pochodzi ze świetlówek znajdujących się w podłodze wybiegu zimne oświetlenie odbija się od satynowej sukni narratorki. Jeśli zestawimy to $\mathrm{z}$ odbiciem kobiety $\mathrm{w}$ pleksowym podeście, ulegniemy złudzeniu, że przypomina ona nimfę przeglądającą się w tafli wody bądź zjawę - to znów efekt zastosowania estetyki lustrzano-ekranowej.

Ważnym elementem nawiązującym do tej estetyki i kształtującym świat przedstawiony jest op e rowanie światłem i cieniem w sposób przywodzący na myśl oświetlenie charakterystyczne dla teatru ekspresjonistycznego. Źródła światła są różne. Przede wszystkim ogniskujące światło sceniczne rozmieszczone dość wyjątkowo: rząd reflektorów intensywnie oświetla tył sceny - krwistoczerwoną kurtynę, natomiast przód oświetlany jest miejscowo przez dwa usytuowane w dole sceny reflektory - imitację dawnej rampy. Światła robocze reflektorów znajdujących się w tyle sceny sprawiają, że większa cześć przestrzeni jest wyciemniona, postaci są wątle oświetlone od tyłu.

Niekiedy światło górnych lamp tworzy kręgi, które, wbrew pozorom, nie służą ekspozycji postaci czy przedmiotów, jak to ma miejsce zarówno w teatrze, jak i w kinie ekspresjonistycznym ${ }^{16}$; w spektaklu Garbaczewskiego często bywa, że są skierowane w pustkę. Nie oświetlają widzowi tego, co powinien zobaczyć, raczej pomagają mu uświadomić sobie, czego zobaczyć nie może (il. 1). Resztę przestrzeni, dość ciemną, niekiedy rozświetla rząd reflektorów znajdujących się bliżej widowni. Jest to światło mające robić wrażenie naturalnego, spłaszczające świat przedstawiony.

Innymi źródłami światła wprowadzającymi atmosferę grozy są niektóre rekwizyty: telewizor, lampa biurowa i rzutnik. Najciekawszy efekt daje użycie tego ostatniego urządzenia. Kiedy profesor Skoliński ogląda na ekranie telewizora nagranie byłego sekretarza księcia, na którym ten relacjonuje

16 L.H. Eisner, Magia światła. Półmrok, [w:] eadem, Ekran demoniczny, tłum. K. Ebenhardt, Warszawa 1974, s. 55. 


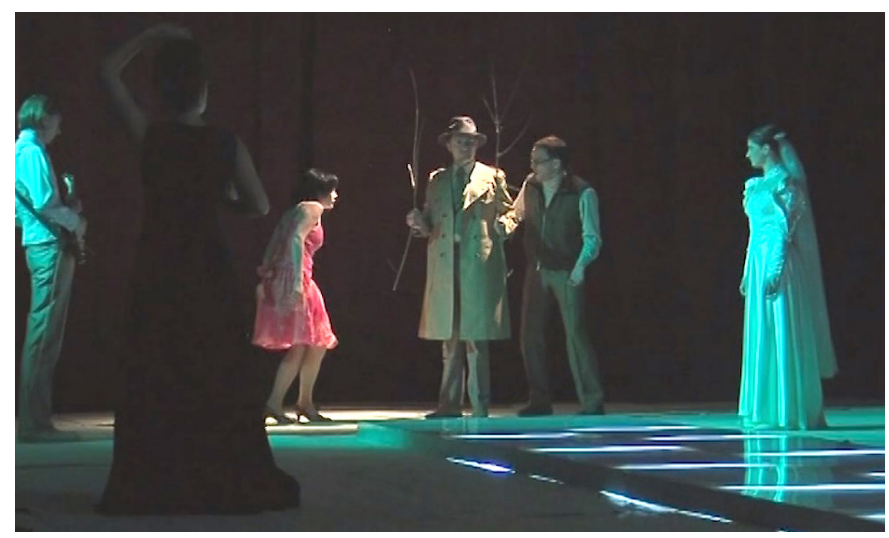

Il. 1. Scena poszukiwania Leszczuka. Maja i Hińcz trafiają na ślad „nienaturalnie” obdrapanego drzewa, które ma być tropem w poszukiwaniach trenera (K. Garbaczewski, Opętani, Teatr Dramatyczny w Wałbrzychu, 2008)

noc w starej kuchni, narasta w profesorze strach. Historyk ogląda budzące niepokój nagranie zrealizowane kamerą „z ręki”, siedząc na krześle usytuowanym bezpośrednio pod światłem lampy rzutnika. Kiedy zaczyna powoli wstawać, przeraża go własny cień, który pojawia się na ekranie (il. 2). Scena ta nie tylko jest oczywistym nawiązaniem do kina czasów ekspresjonizmu niemieckiego, kiedy to wyolbrzymiony cień na opalizującej płaszczyźnie jawi się jako zły sobowtór ${ }^{17}$; Garbaczewski również kompromituje w niej grozę Gombrowiczowskiej historii, wprowadzając bohatera, który „boi się własnego cienia” (i sugerując poniekąd widzowi, że to, czego się boimy, ma źródło w naszym działaniu).

Opętani, mimo swej nowoczesnej formy, są spektaklem nawiązującym do teatru ekspresjonistycznego nie tylko poprzez użycie światła, ale również przez połączenie form dramatycznych, z którymi ów teatr eksperymentował. Ślady estetyki tegoż znajdziemy również w egzaltowanej grze aktorskiej (głównie w przypadku Marty Zięby, grającej hrabinę, oraz Krzysztofa Zalewskiego, wcielającego się w rolę Hińcza), za pomocą której twórca pragnął pokazać w krzywym zwierciadle papierowość postaci z powieści popularnych.

17 Zob. L.H. Eisner, $W$ świecie cieni i odbić lustrzanych, [w:] eadem, Ekran demoniczny, op. cit., s. 99. 


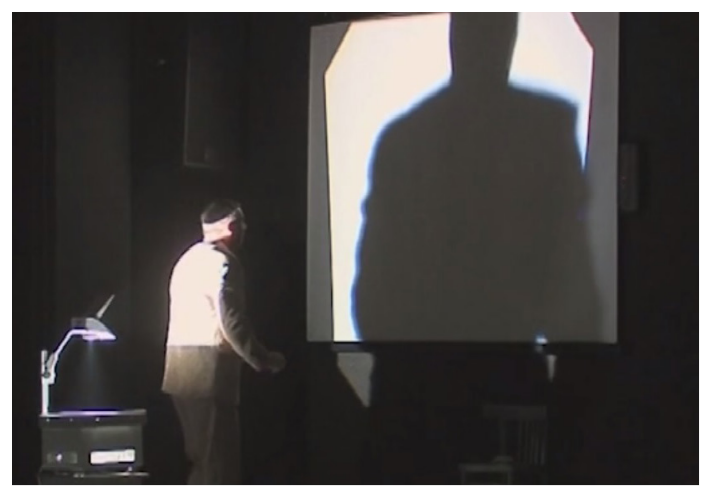

Il. 2. Profesor Skoliński, w którym lęk budzi jego własny cień (K. Garbaczewski, Opętani, Teatr Dramatyczny w Wałbrzychu, 2008)

Gombrowicz w Opętanych - zgodnie ze swoją filozofią - afirmuje zarówno gatunki, formy, jak i motywy literackie wiązane z kulturą niską. Elementy powieści grozy, kryminału i romansu, jak zwraca uwagę Agnieszka Fulińska ${ }^{18}$, mogą być kojarzone ze sobą w tekście kultury popularnej z uwagi na łączące je archetypy, na których bazują (walka dobra ze złem, przywracanie porządku świata itp.). Na istotności traci również linearno-powrotna narracja wątku kryminalnego wobec nagromadzenia linii fabularnych. Za tym pomysłem pisarza podąża w swoim spektaklu reżyser, sięgając po odniesienia i dodatkowe rozwiązania charakterystyczne dla gatunków literackich i filmowych oraz form performatywnych.

\section{ASPEKTY PRZESTRZENI TEATRALNEJ OPETANYCH GARBACZEWSKIEGO}

\section{A) (META)SCENOGRAFIA}

Garbaczewski wykorzystuje aspekt teatralności utworów prozatorskich Gombrowicza, w swoisty sposób intensyfikując go poprzez zmianę medium. Reżyser kreśli wizję współistnienia i interakcji ludzi, ujmując je jako formę

18 A. Fulińska, Dlaczego literatura popularna jest popularna?, „Teksty Drugie” 2003, nr 4, s. 60. 
nieuchronnego bycia-wobec-widowni ${ }^{19}$. Podczas spotkania ze spektaklem Garbaczewskiego konfunduje widza przedziwna, niejednoznaczna przestrzeń. Tył sceny zasłonięty jest tradycyjną bordową kurtyną, na scenie poustawiano przedmioty nietworzące spójnego świata scenicznego: pralkę, telewizor, projektor, metalowe łóżko i wieszak na ubrania. Zdaje się, że mamy przed sobą nie scenę, ale garderobę, skład rekwizytów i kostiumów (il. 3). Widzimy „drugą stronę” - to, co w normalnych warunkach pozostaje ukryte. Ponadto scena wyposażona jest w wybieg, co z kolei przywodzi na myśl sceny estradowe lub te przeznaczone do organizacji pokazów mody. $\mathrm{Na}$ początku trzeciego aktu wszyscy bohaterowie wychodzą na wybieg w rytm kakofonicznie połączonych utworów disco - to nie pokaz mody, ale prezentacja gombrowiczowskich typów, jak gdyby reżyser kolejny raz chciał przypomnieć widzom, że mają przed sobą pozy ludzkie, nie osobowości, że uczestniczą w festiwalu demaskowanych „gęb”. Na dodatek twórcy zaskakują widzów teatralnym „efektem fałszywego zakończenia” ${ }^{20}$ : bohaterowie kłaniają się, biją sobie wzajemnie brawa, pojawia się nawet konfetti. Wszystko wskazuje na koniec przedstawienia. Kiedy jednak bohaterowie schodzą ze

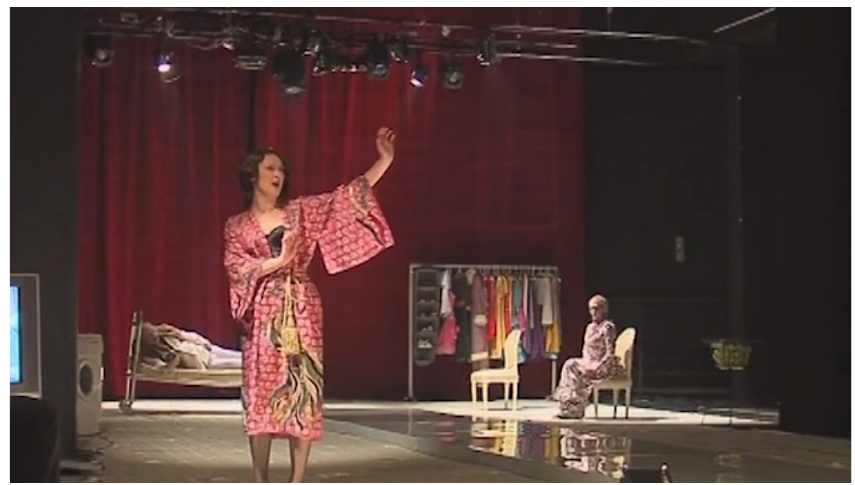

Il. 3. Hrabina di Mildi i Maja Ochołowska odnajduja martwego Maliniaka (K. Garbaczewski, Opętani, Teatr Dramatyczny w Wałbrzychu, 2008)

19 J. Jopek, Widz wywłaszczony. Subwersywne gry z biernością odbiorcy $w$ teatrze Krzysztofa Garbaczewskiego, „Polish Theatre Journal” 2016, nr 2.

20 B. Uspienski, Poetyka kompozycji. Struktura tekstu artystycznego i typologia form kompozycji, tłum. P. Fast, Katowice 1997, s. 212. 
sceny, Maja z Leszczukiem, zamiast wejść za kulisy, wybiegają, trzymając się za ręce - „tak jakby do ukłonów”, po czym... zaczynają tańczyć do niegdyś popularnego utworu zespołu Tatu Nas nie dogoniat.

Kolejnym ciekawym rozwiązaniem scenograficznym, podkreślającym jawną teatralność świata przedstawionego, jest konstrukcja pokoju Leszczuka (akt trzeci). Kiedy oszalały tenisista zostaje znaleziony u Handrycza/Frania, Maja wraz z Hińczem transportują go do dworu w Połyce. W spektaklu pokój ten jest zbudowany ze ścian trzymanych przez Profesora, Hińcza i Maję (il. 4). Takie rozwiązanie, z jednej strony, można uznać za wizualizację utrzymywania pozorów (poza Mają nikomu nie zależy na dobru Leszczuka, lecz na rozwiązaniu zagadki jego szaleństwa i wyjaśnieniu powiązań chłopaka z nawiedzonym zamkiem w Mysłoczy). Z drugiej zaś mobilna konstrukcja pokoju pomaga zaprezentować podczas dochodzenia dotyczącego śmierci Maliniaka sposób, w jaki został zamordowany przez hrabinę di Mildi (Marta Zięba).

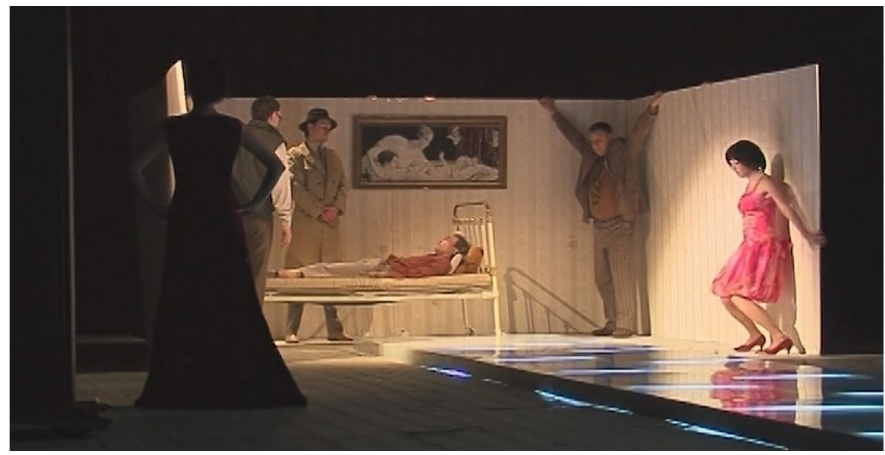

Il. 4. Przesłuchanie Leszczuka w sprawie śmierci Maliniaka (K. Garbaczewski, Opętani, Teatr Dramatyczny w Wałbrzychu, 2008)

Metarefleksyjny rys przestrzeni scenicznej okaże się narzędziem demaskującym kabotynizm bohaterów. W tym kontekście ogromnie ważną rolę pełni wykorzystana w spektaklu e s te t y ka lu st r za no - ek ra nowa: obecne na scenie ekrany zniekształcają zapośredniczone przez nie obrazy ${ }^{21}$.

${ }^{21}$ Zob. M. Błaszczak, Lustrzano-ekranowa estetyka, [w:] eadem, Ekrany i lustra w polskim dramacie współczesnym, Poznań 2009, s. 241-244. 
W scenie, w której były sekretarz Księcia, Rudziański (Łukasz Brzeziński), prezentuje zamek Holszańskiego i zachwala jego architekturę, na projektorze widzimy zniekształcony, wydłużony obraz dwupiętrowej kamienicy z ryzalitem w części środkowej budynku, nie zaś strzelisty, gotycki gmach. Kolejnym medium zniekształcającym przekaz jest kamera cyfrowa. Nagrywa się nią najpierw Maliniak, który w otwierającej scenie pierwszego aktu prowadzi narrację „transmitowaną na żywo” na ekranie telewizora. W tym przypadku mamy powielony obraz: widzimy Maliniaka zarówno leżącego na łóżku, jak i na ekranie telewizora (il. 5). Obrazy różnią się od siebie - drugi z nich został przefiltrowany przez medium ekranu. W drugim akcie z kolei za pośrednictwem telewizora profesor ogląda nagranie Rudziańskiego, który relacjonuje swój pobyt w rzekomo nawiedzonej kuchni. W obu przypadkach twarze ulegają demonicznemu zniekształceniu, głównie ze względu na niewielką odległość kamery. Taki sposób obrazowania związany jest też z częstą w spektaklach Krzysztofa Garbaczewskiego hiperbolą wizualną zarówno całe twarze, jak i poszczególne ich części są nam przybliżane, co prowadzi do efektu wyolbrzymienia.

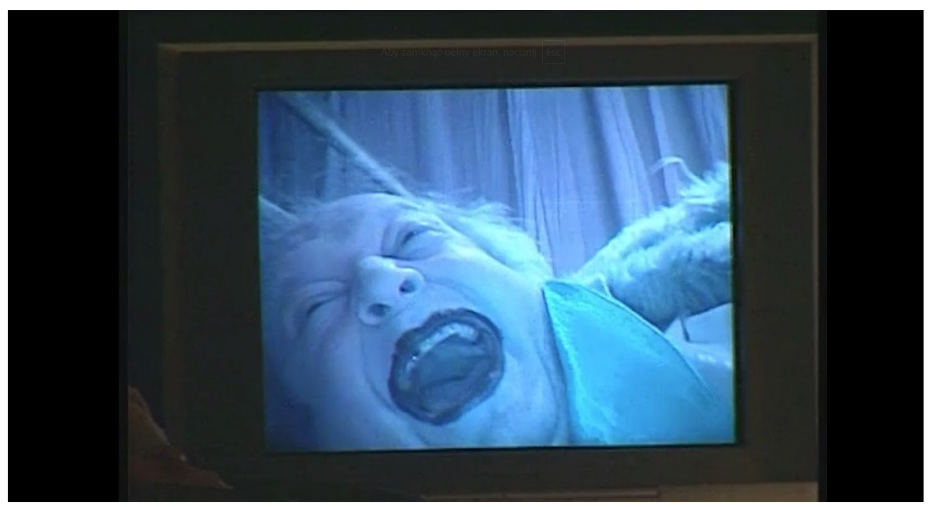

Il. 5. Telewizor, na którym widzowie ogladaja wyolbrzymiona twarz Maliniaka (K. Garbaczewski, Opętani, Teatr Dramatyczny w Wałbrzychu, 2008)

\section{B) ZNIEKSZTAŁCAJĄCE MIKROŚWIATY (STREFY)}

Opętani to spektakl, który nie wpisuje się jeszcze w dzisiejszy teatr Krzysztofa Garbaczewskiego, korzystający w sposób wyraźny z narracji plastycznej i intermedialnej. Scenografia Anny Marii Kaczmarskiej jest ascetyczna, estetyką 
zbliżona do teatru Krystiana Lupy, składająca się głównie z przedmiotów używanych i "gotowych do wykorzystania” w konkretnych scenach (por. il. 3). Jak pisze Joanna Jopek:

Łóżko dla Maliniaka. Pralka automatyczna z wirującymi światełkami dla Pani Ochołowskiej (Irena Wójcik), która siada na niej, czytając swój list do córki - ostrzeżenie przed pułapkami młodości. Wieszak z ubraniami dla Mai i na potrzebę jednej sceny - kiedy bohaterowie ukrywają się w „szafie”. Rakietki tenisowe. Rzutnik dla profesora sztuki zainteresowanego zawartością zamku w Mysłoczy. Bieżnia dla narzeczonego, który „biegnie” do swojej ukochanej22.

Postaci mają na sobie stroje, które jeśli nie są wprost „z epoki”, to przynajmniej ją przywołują, a wspomniane przez badaczkę rekwizyty współczesne (telewizor, projektor) pełnią m.in. funkcję poszerzania przestrzeni scenicznej (na ekranie telewizora widzimy to, co tu i teraz, natomiast na planszy rzutnika - obiekty z przeszłości). Wymienione elementy scenografii wyznaczają st r e f $\mathrm{y}^{23}$, miejsca szczególne, ściśle związane z poszczególnymi bohaterami bądź ich emocjami.

Najistotniejszą strefą w spektaklu Garbaczewskiego jest niewątpliwie w y bieg, pełniący jednocześnie kilka funkcji. Na jego brzegu siedzi Markiza di Mildi, kiedy składa zeznania po śmierci Maliniaka. Przed wstąpieniem

22 J. Jopek, Parę spojrzeń w lustro, „Didaskalia. Gazeta Teatralna” 2009, nr 89, s. 23.

${ }^{23}$ Pojęcie strefy Garbaczewski zapożyczył od Krystiana Lupy, z którym współpracował m.in. przy okazji Factory 2, ten z kolei zaczerpnął je od Andrieja Tarkowskiego. „Pojęcie strefy Lupa zaczerpnął zainspirowany jego filmem Stalker. W filmie strefa stanowi obszar czasoprzestrzeni, w którym zostaje maksymalnie rozbudzona wrażliwość człowieka. Tytułowy bohater filmu Tarkowskiego wymyślił "to miejsce, by sprowadzać ludzi i przekonywać ich o prawdzie swojego tworzenia; [...] aby stworzyć jakąś wiarę, wiarę w jego rzeczywiste istnienie«. Sfera traktowana jest jako przestrzeń rytualna, nasycona energią, miejsce symboliczne i graniczne, miejsce objawień nowego kształtu, w których na styku Mętnej Energii ze szczątkami umarłej formy dokonuje się alchemia przemiany”; A. Zalewska-Uberman, Słownik Krystiana Lupy. Perspektywa reżysera, „Didaskalia. Gazeta Teatralna” 2010, nr 96, s. 19. 
na podest mocno tupie nogą, a ruch ten, jak się wydaje, uruchamia świetlówki ukryte w podłodze. Kobieta „teatralnym”, zamaszystym krokiem przemierza podest aż do jego skraju, powtarzając cały czas, jakby chcąc zahipnotyzować śledczych: „ja, ja, ja”. W trakcie zeznania przez przypadek ujawnia, że to „najdziwniejsza zbrodnia, o jakiej czytała”, czym sprowadza na siebie podejrzenie uśmiercenia krewnego.

$\mathrm{Na}$ podeście stoi narratorka (panna młoda) opowiadająca o zamku w Mysłoczy, tam też ma miejsce monolog Walczaka dotyczący jego trudnego dzieciństwa. Na skraju wybiegu siedzi sługa Grzegorz opowiadający dramatyczną historię Frania. Migający zimnym światłem wybieg odgrywa też rolę szafy, w której Ochołowska i jej trener spotykają się przypadkiem, i to na wybiegu ma miejsce scena zamiany ubrań (symbol romantycznych uniesień kochanków?). Pobłyskujący zimnym światłem podest staje się więc „przestrzenią prawdy” (w przypadku zeznań di Mildi), miejscem ujawniania się intymnych relacji (sceny z Mają i Leszczukiem) i wyznawania wstydliwych tajemnic (Leszczuk i sługa Grzegorz). Strefa ta pełni funkcję mi iej s ca, w którym bohaterowie przechodzą chwilowe przemiany i w prowadzani są w dziwne stany, ale to również przestrzeń, gdzie bohaterowie konfrontują się ze swoją tożsamością, poznają siebie.

Wybieg pełni w spektaklu również rolę "generatora atmosfery grozy”, jest bowiem scenicznym ekwiwalentem powieściowego ręcznika, którym rzekomo miał być uduszony Franio. Podczas całkowitego wyciemnienia przestrzeni w niektórych momentach jedyne źródło światła stanowią panele ledowe umieszczone w podeście. Intensywne, ale wąskie snopy światła złowrogo zniekształcają postaci, które znajdują się na scenie. Miast rozjaśniać, porządkować przestrzeń, czynią ją nieczytelną, czasem budzącą grozę (por. il. 1 i 8). Kiedy któryś z bohaterów nastąpi na wybieg, świetlówki zaczynają automatycznie migać, jak gdyby powstawało w nich zwarcie. Nagle gasnące światło niepokoi i straszy, a co najistotniejsze - wywołuje stany chorobowe podobne do padaczki. Tak dzieje się w przypadku Hińcza. Jasnowidz ma wizje, gdy staje na wybiegu, niekiedy wręcz wije się z przerażenia, doświadczając owego „zła”, które wisi nad Mysłoczą i Połyką. Co więcej, podest (z uwagi na to, że wykonany został z niestabilnej pleksy) rusza się, trzęsie i wibruje pod wpływem ruchów, tak jak poruszany przez powietrze ręcznik. 


\section{KU INTERPRETACJI: HISTORIE WYKLUCZONYCH I PYTANIA O TOŻSAMOŚĆ}

Reżyser ogranicza w swojej inscenizacji część warszawską, którą właściwie wypełnia wątek morderstwa Maliniaka i historia jasnowidza Hińcza. Co jednak istotniejsze dla wymowy przedstawienia, usunięto wątek bójki pomiędzy Mają i Leszczukiem, a ich relacja została zeufemizowana, pozbawiona demonicznego, „dzikiego” pierwiastka. Tym samym twórca rezygnuje z wizji miasta jako miejsca żywotnego, nieokrzesanego. W powieści Gombrowicza istotny jest wątek Warszawy jako miejsca, w którym jak w soczewce widać zmiany społeczne i obyczajowe, demokratyzację życia, ale również degradację „tradycyjnych wartości”.

Maria Janion w wątku Mai i Leszczuka doszukiwała się również gotyckiego demonizmu. Dowodziła, iż motyw ten jest pokłosiem fascynacji Gombrowicza złem ${ }^{24}$. Z kolei Jerzy Jarzębski czytał go jako model relacji perwersyjnej, masochistycznej, obecny także w innych dziełach pisarza ${ }^{25}$. Nie brak hipotez, że wątek ten stanowi pokłosie niepokoju związanego z młodym pokoleniem zafascynowanym faszyzmem. Pisarz podczas swoich młodzieńczych wyjazdów spotykał i z przerażaniem obserwował młodych Europejczyków, zdeterminowanych, by walczyć w obronie ideologii, nawet za cenę zniszczenia europejskiego dziedzictwa kulturowego ${ }^{26}$. Demonizm obecny w powieści realizuje się w spektaklu jednak nie poprzez ideologiczne „opętanie” pary głównych bohaterów, ale w eksponowaniu wątków związanych ze w st yd e m oraz społecznym i klasowym w yklucze n ie m.

Wstydem jest naznaczona przede wszystkim relacja Księcia Holszańskiego i jego syna z nieprawego łoża - Frania. Garbaczewski w swoim teatrze uczynił z figury ojca jeden z najbardziej rozpoznawalnych motywów (wystarczy wspomnieć Odyseję i Chłopów). Figury te wprawdzie nie są postaciami centralnymi, ale zawsze istotnymi, częstokroć wprowadzającymi przemoc. Nie inaczej dzieje się w inscenizacji z 2008 roku. Jedna z pierwszych scen drugiego aktu zostaje poświęcona relacji ojca-księcia i syna zrodzonego z matki-chłopki. Relacja ta w spektaklu jest społecznie nieakceptowana i wstydliwa w dwójnasób: z jednej strony związana z klasowym niedopasowaniem,

${ }^{24}$ M. Janion, op. cit., s. 174

25 J. Jarzębski, op. cit. s. 78.

26 K. Suchanow, Gombrowicz. Ja, geniusz, Wołowiec 2017, s. 206. 
z drugiej zaś wykreowana na homoerotyczne, a zarazem kazirodcze uczucie, jakim Książę darzy syna.

Historia syna $\mathrm{z}$ nieprawego łoża zostaje zaprezentowana $\mathrm{w}$ jednej z pierwszych scen drugiego aktu. Grzegorz (Ryszard Węgrzyn), stary sługa Holszańskiego, opowiada tu o losach Frania i Księcia. Scena jest niemal zupełnie wyciemniona, jedynym źródłem światła pozostaje reflektor podświetlający postaci tylko tyle, by widać było ich czarne sylwetki, widownia natomiast zostaje owym światłem oślepiona; ledwie dostrzec może półnagie ciała aktorów. Intymność sceny zostaje również podkreślona przez sposób, w jaki Grzegorz opowiada historię ojca i syna. Narrator-sługa komentuje wydarzenia $\mathrm{z}$ krzesła usytuowanego na skraju wybiegu przecinającego widownię i opowiada historię rodzinną przez megafon. Zabieg ten sprawia, że głos Grzegorza jest donośny, ale niewyraźny. Zarówno ów dźwięk, jak i oświetlenie stanowią doskonały komentarz do sceny prezentującej wstydliwą relację. Jak pisze Paweł Leszkowicz: światło intensywne, palące, symbolizuje relacje patriarchalne, może oznaczać karzącego ojca ${ }^{27}$. Oczywisty lęk przed ciemnością przykuwa wzrok widza do jasności, która nie daje otuchy, lecz budzi niepokój. Książę wprawdzie nie wrzuca - jak mu się wydaje martwego Frania do starego pieca (tak wykreował tę historię Gombrowicz); syn po prostu znika za kotarą. Garbaczewski wraca do tego wątku w trzecim akcie, ukazując Księcia (Dariusz Maj) grającego na trąbce „do kotary”, za którą zniknął Franio, piosenkę Violetty Villas Do Ciebie, mamo (il. 6).

Reżyser nie przywołuje jednak postaci Handrycza, czyli dorosłego Frania, który szczęśliwie przeżył, zbiegł z zamku, stracił pamięć, a następnie został przypadkowo odnaleziony przez opętanego Leszczuka na wsi w pobliżu Mysłoczy. Holszański nie zazna spokoju, nie zyska przebaczenia swojego syna, nie wyzwoli się z tytułowego „opętania”, nie pozbędzie się moralnej skazy. Garbaczewski, wykorzystując fakt, że Gombrowicz zmienił nazwisko swojemu bohaterowi, postanawia podwoić postać trenera tenisa - w spektaklu mamy zarówno Leszczuka (Rafał Kosowski), jak i Walczaka (Paweł Smagała), który jednocześnie gra rolę Frania. Taki zabieg nie tylko stanowi realizację motywu sobowtóra, obecnego w twórczości Gombrowicza, ale

27 P. Leszkowicz, Sztuka światła w światłach reflektorów, [w:] Światło obrazu. Wykłady otwarte, red. M. Rochowski, kurator M. Dziewulska, Warszawa 2007, s. 207. 


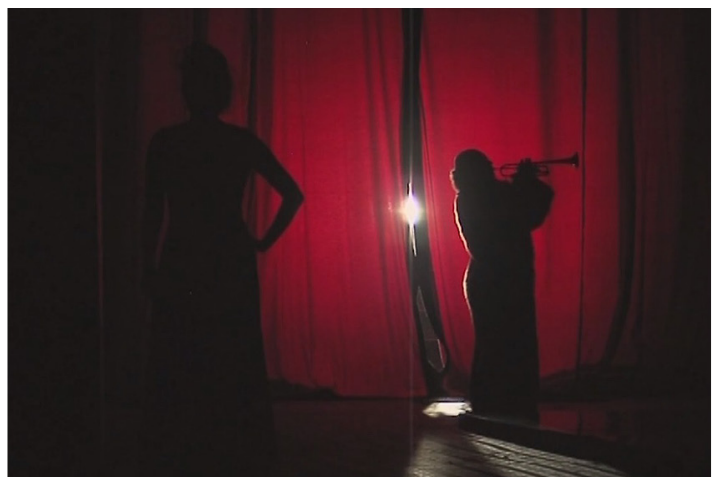

Il. 6. Książę Holszański grający Franiowi na trąbce Do Ciebie, mamo (K. Garbaczewski, Opętani, Teatr Dramatyczny w Wałbrzychu, 2008)

przede wszystkim kreuje figurę syna - człowieka niedojrzałego, obarczonego jarzmem wstydu, odrzuconego przez ojca i poszukującego siebie.

Kolejnym wykluczonym jest Marian Leszczuk - pogardzany ze względu na swoje pochodzenie i „prostackie” cechy, budzący mieszane uczucia z uwagi na wykonywany zawód. W pierwszym akcie dysonans pomiędzy panną Ochołowską (Paulina Chapko) a trenerem jest budowany za pomocą stroju, szczególnie wyeksponowany, kiedy oboje grają w tenisa: ona w błękitnej sportowej spódniczce i śnieżnobiałej bluzce, on w swoim codziennym ubraniu - brązowawych spodniach na szelkach, musztardowej koszuli i kaszkiecie. Przepaść klasowa najbardziej widoczna jest w obuwiu graczy. Maja ma na sobie biało-błękitne buty typu Nike Blazer, zaś jej partner - materiałowe, tanie „halówki”. Poza strojem istotne jest również to, w jaki sposób Leszczuk i Ochołowska są oświetlani na scenie w momentach konfrontacji: Maja występuje w niemal pełnym, wręcz oślepiającym świetle, które dodatkowo odbija się od jej jasnego ubrania, natomiast Leszczuk pozostaje ledwie widoczny, najczęściej oświetlany światłem odbitym, nie reflektorem (il. 7).

Namiętność, w powieści naznaczona agresją, w spektaklu przekształcona jest w szczerą, młodzieńczą relację miłosną. Krwawa w skutkach bójka Ochołowskiej i Leszczuka, która stała się powodem ucieczki obojga z majątku w Połyce, zostaje zastąpiona symboliką aktu miłosnego. Kiedy już bohaterowie ze zdziwieniem przekonają się o swoim wzajemnym podobieństwie („MAJA: Aha, to ja jestem taka? A ty taki! / LESZCZUK: Aha, to ja 


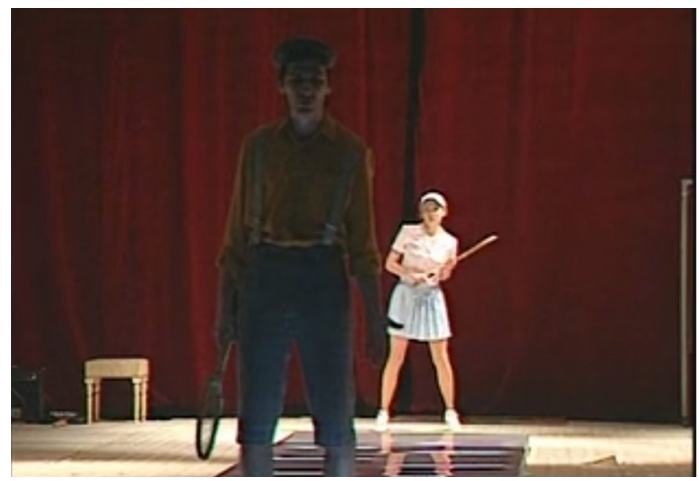

Il. 7. Scena gry w tenisa (K. Garbaczewski, Opętani, Teatr Dramatyczny w Wałbrzychu, 2008)

jestem taki? A ty taka?”), zamieniają się ze sobą ubraniami. Scena nie tylko wyraża relację romantyczną, ale pełni również rolę aktu spajającego przedstawicieli różnych klas oraz implikuje pytanie o tożsamość postaci (il. 8). Przedstawienie bowiem zamyka wielokrotnie powtarzane przez Hińczamedium pytanie: „Kim jesteś?”.

Reżyser, drążąc w swoim spektaklu problem wykluczenia, nie ogranicza się wyłącznie do postaci Leszczuka i Frania. W niezwykle interesujący sposób wplata klasowy konflikt pomiędzy metropolią (Warszawą) a prowincją (lubelską wsią), jednostkami ukształtowanymi przez kulturę a „dzikimi”. W tym celu posługuje się nawiązaniem do westernu. Właściciel wiejskiego hotelu, do którego początkowo trafia zbiegły ze stolicy Leszczuk, w spektaklu jest Meksykaninem w ogromnym sombrero na głowie i cygarem w ustach. Biorąc pod uwagę fakt, że Meksykanin w klasycznym westernie kreowany był na chytrego prostaka-nikczemnika, Garbaczewski zdaje się przywoływać stereotyp rolniczej Lubelszczyzny znajdującej się w „Polsce B”, na której - jak mówi sama Maja - panuje „dzicz i ubóstwo”28. Tak jak w westernach pokazywano spotkanie cywilizowanego Amerykanina i dzikiego Meksykanina, tak w spektaklu kształtuje się zderzenie polskiej prowincji z „cywilizowaną”

28 M.F. Gawrycki, Bardziej Dziki Zachód. Meksyk i Meksykanie w hollywoodzkich westernach, Toruń 2011. Warto zaznaczyć, że o takim wizerunku Meksykanina w kulturze masowej pisał George Orwell: Tygodniki dla chłopców, [w:] idem, Anglicy i inne eseje, tłum. B. Zborski, Warszawa 2002, s. 33-73. 


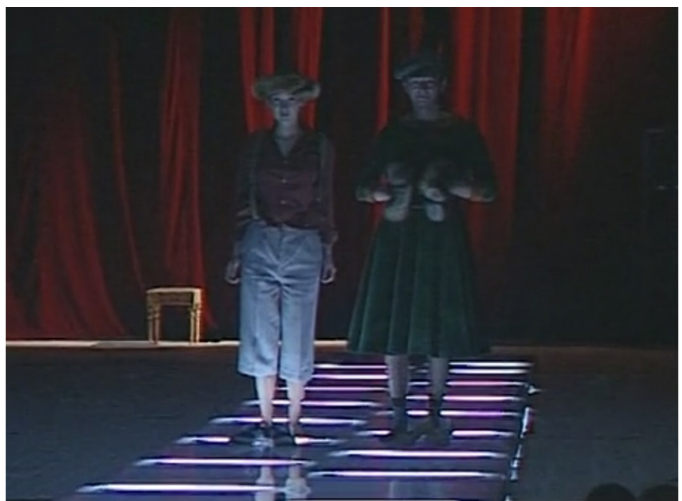

Il. 8. Scena zamiany ubrań (K. Garbaczewski, Opętani, Teatr Dramatyczny w Wałbrzychu, 2008)

Mają i jej przyjacielem Hińczem, którzy właśnie wracają ze stolicy. Z drugiej strony taki zabieg konotuje również fascynację prowincji szeroko pojmowanym Zachodem. Skojarzenie to nasuwa się przede wszystkim z uwagi na fasadę hotelu, w którym przebywa Leszczuk (il. 9). Biały siding elewacyjny przywodzi na myśl amerykańskie domy; jak zwraca uwagę Joanna Plit, stał się on szczególnie popularny na przełomie XX i XXI wieku, gdy budynki zbudowane $z$ tradycyjnych materiałów (m.in. z kamienia i drewna) obudowywało się oblicówką w celu nadania im współczesnego wyglądu ${ }^{29}$.

\section{PODSUMOWANIE}

Reżyser, przy zachowaniu szacunku do charakteru twórczości autora, dekonstruuje Opętanych, wydobywając elementy wpisujące się we współczesne refleksje humanistyczne dotyczące tożsamości (płciowej, klasowej, ale nie tylko), a zarazem otwiera powieść Gombrowicza, udowadnia, jak wielowymiarowa może się okazać w interpretacji. Nie bez znaczenia pozostają tu przekształcenia zarówno strukturalne, jak jakościowe dokonane przez teatralnego twórcę. Garbaczewski żongluje fabułą tam, gdzie jest ona zaledwie zarysowana, często myli odbiorcze tropy, zwodzi widza. W rezultacie bowiem w inscenizacji nie chodzi ani o powieść gotycką, ani tym bardziej

29 J. Plit, Krajobrazy kulturowe Polski i ich przemiany, Warszawa 2016, s. 323. 


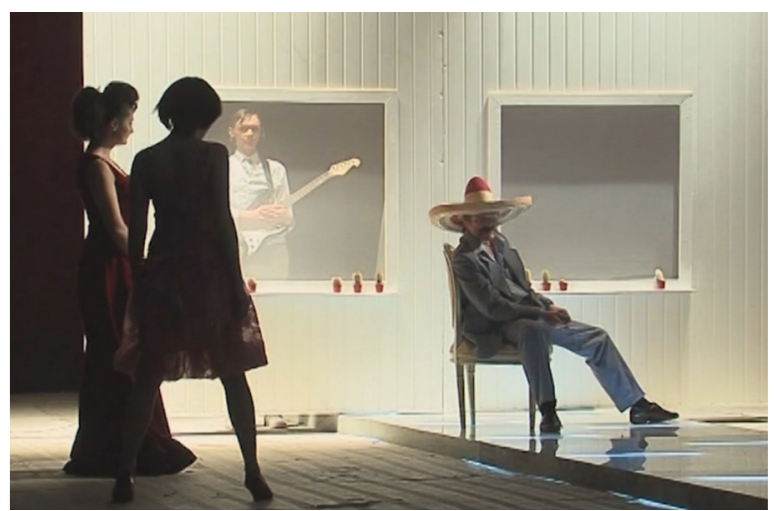

Fot. 9. Scena poszukiwania Leszczuka w hotelu na lubelskiej prowincji (K. Garbaczewski, Opętani, Teatr Dramatyczny w Wałbrzychu, 2008)

o zagadkę kryminalną (wszak od pierwszej sceny wiadomo, kto Maliniaka zamordował).

W konkluzji trudno nie powrócić do ostatniej sceny spektaklu, w której Hińcz uporczywie zadaje (również widowni) pytanie: „Kim jesteś?”. Pełne patosu zakończenie zdaje się nie pasować do spektaklu. Garbaczewski stawia Hińcza nie w roli rekonstruktora czy reżysera zbrodni (jak czyniła to Maria Janion, zestawiając tę postać ze śledczym ze Zbrodni z premedytacją czy Fryderykiem z Pornografii), ale kogoś naiwnego i śmiesznego w swej nieudolności. Kreowany jest on w przedstawieniu na człowieka opętanego, miotającego się podczas swoich rzekomych wizji. Reżyser nie zamierza pokazać zła, z którym Hińcz walczy, jako atmosfery, energii związanej z oddziaływaniem zewnętrznych lub wewnętrznych nawet sił. Rezygnuje z niektórych motywów obecnych w powieści, często je upraszcza lub udosławnia. Garbaczewski próbuje opowiedzieć poprzez historię powieściową, przefiltrowaną przez użyte znaki sceniczne, zupełnie inną, bardzo prostą historię zła, którego źródłem jest ludzka chciwość (Cholawicki, markiza Di Mildi) i destrukcyjna pogarda wobec drugiego człowieka (Holszański). Tymczasem dobroduszny Hińcz zdaje się szukać zła tam, gdzie go nie ma poza człowiekiem. 


\section{Bibliografia}

Monika Błaszczak, Lustrzano-ekranowa estetyka, [w:] eidem, Ekrany i lustra w polskim dramacie wspótczesnym, Wydawnictwo Poznańskiego Towarzystwa Przyjaciół Nauk, Poznań 2009.

Lotte H. Eisner, Ekran demoniczny, tłum. K. Ebenhardt, Wydawnictwo Artystyczne i Filmowe, Warszawa 1974.

Energia. Rozmowa Romana Pawłowskiego z Krzysztofem Garbaczewskim, „Notatnik Teatralny" 2016, nr 82.

Agnieszka Fulińska, Dlaczego literatura popularna jest popularna?, „Teksty Drugie” 2003, nr 4.

Marcin F. Gawrycki, Bardziej Dziki Zachód. Meksyk i Meksykanie w hollywoodzkich westernach, Wydawnictwo Adam Marszałek, Torun 2011.

Ewa Graczyk, Widmo Opętanych, [w:] eidem, Przed wybuchem wstrząsnąć, Słowo/ obraz terytoria, Gdańsk 2004.

Maria Janion, Forma gotycka Gombrowicza, [w:] eidem, Goraczka romantyczna, PIW, Warszawa 1975.

Jerzy Jarzębski, Opętani - zapomniana powieść Gombrowicza, [w:] idem, Powieść jako autokreacja, Wydawnictwo Literackie, Kraków 1984 [pierwodruk: „Twórczość” 1972, nr 4].

Joanna Jopek, Parę spojrzeń w lustro, „Didaskalia. Gazeta Teatralna” 2009, nr 89. Joanna Jopek, Widz wywłaszczony. Subwersywne gry z biernościa odbiorcy w teatrze Krzysztofa Garbaczewskiego, „Polish Theatre Journal” 2016, nr 2.

Marcin Kościelniak, Pokolenie wieszaka, „Tygodnik Powszechny”, 17.02.2009, https://www.tygodnikpowszechny.pl/pokolenie-wieszaka-136116.

Hans-Thies Lehmann, Parataksa / Brak hierarchii, [w:] idem, Teatr postdramatyczny, tłum. D. Sajewska, M. Sugiera, Księgarnia Akademicka, Kraków 2009.

Paweł Leszkowicz, Sztuka światła w światłach reflektorów, [w:] Światło obrazu. Wykłady otwarte, red. M. Rochowski, kurator M. Dziewulska, Teatr Narodowy, Warszawa 2007.

George Orwell, Tygodniki dla chłopców, [w:] idem, Anglicy i inne eseje, tłum. B. Zborski, Muza, Warszawa 2002.

Brygida Pawłowska-Jądrzyk, Młodość jako „sekretna alchemia odciążająca”. W kręgu idei Witolda Gombrowicza, [w:] Ciężar i lekkość w kulturze. Estetyka, poetyka, style myślenia, red. B. Pawłowska-Jądrzyk, WN UKSW, Warszawa 2016.

Joanna Plit, Krajobrazy kulturowe Polski i ich przemiany, IGiPZ PAN, Warszawa 2016. 
Klementyna Suchanow, Gombrowicz. Ja, geniusz, Wydawnictwo Czarne, Wołowiec 2017.

Wojciech Śmieja, Od ideologii ciała do cielesności zideologizowanej. Sport i literatura w latach 1918-1939, „Teksty Drugie” 2011, nr 4.

Boris Uspienski, Poetyka kompozycji. Struktura tekstu artystycznego i typologia form kompozycji, tłum. P. Fast, „Śląsk”, Katowice 1997.

Anna Zalewska-Uberman, Słownik Krystiana Lupy. Perspektywa reżysera, „Didaskalia. Gazeta Teatralna” 2010, nr 96.

Żelisław Żelisławski, Uruchom ponownie. Strategie estetyczne i przeciwreżyserskie Krzysztofa Garbaczewskiego, [w:] Odsłony wspótczesnej scenografii. Problemy - Sylwetki - Rozmowy, red. K. Fazan, A. Marszałek, J. Rożek-Sieraczyński, WUJ, Kraków 2016.

\section{Źródło ilustracji}

Zrzuty ekranu $\mathrm{z}$ rejestracji spektaklu dostępnej na koncie Krzysztofa Garbaczewskiego na platformie Vimeo: https://vimeo.com/348662715 [dostęp 5.09.2020].

\section{Possessed in the Theater. Adaptive Measures on Witold Gombrowicz's Novel Staged by Krzysztof Garbaczewski}

The article constitutes an analysis of Krzysztof Garbaczewski's performance Possessed based on Witold Gombrowicz's novel of the same title. The aim of the article is to present the staging that puts Possessed in the context of contemporary humanistic discourses and to reflect on the aesthetic of the performance. The goal is also to analyze the disillusioning tricks used by the director, to point out the convention plays presented in the spectacle and to illustrate the self-referential function of the stage space. The text also outlines the director's adaptation strategy and the use of narration in the staging.

Keywords: Krzysztof Garbaczewski, Witold Gombrowicz, Possessed, 'hanger generation' 